\title{
A contribution to the diagnosis of the small dentigerous cyst or the paradental cyst
}

\section{Contribuição para o diagnóstico do pequeno cisto dentígero ou do cisto paradentário}

\author{
José Humberto DAMANTE* \\ Raul Negrão FLEURY**
}

\begin{abstract}
DAMANTE, J. H.; FLEURY, R. N. A contribution to the diagnosis of the small dentigerous cyst or the paradental cyst. Pesqui Odontol Bras, v. 15, n. 3, p. 238-246, jul./set. 2001.
\end{abstract}

\begin{abstract}
The aim of this study was to verify the relationship between the radiographically measured width of the pericoronal space (PS) and the microscopic features of the follicle in order to contribute to the diagnosis of small dentigerous cysts and paradental cysts. One hundred and thirty unerupted teeth (UT) and thirty-five partially erupted teeth (PET) were radiographed and extracted. The radiographic analysis consisted of measuring the width of the PS. The results of the radiographic analysis were compared with those of the histopathologic examination of the dental follicle. The width of the PS ranged from 0.1 to $5.6 \mathrm{~mm}$. The most frequently observed lining of the follicles was a reduced enamel epithelium (REE) $(68.4 \%)$ in UT and a hyperplastic stratified squamous epithelium (HSSE) $(68.5 \%)$ in PET. Inflammation was present in $36.1 \%$ of the UT and in $82.8 \%$ of the PET. There was a statistically significant association between the presence of stratified squamous epithelium (SSE) and PS enlargement for UT ( $<0.05)$. There was a tendency of association between inflammation and PS enlargements in PET and, possibly, in UT, despite the absence of statistical significance. Surgically, we did not detect bone cavitation or luminal cystic contents in pericoronal spaces smaller than $5.6 \mathrm{~mm}$. We suggest that the first radiographic diagnosis for a PS enlargement, in most of the routine clinical cases, should be of "inflammation of the follicle". The hypothesis of "dentigerous cyst" or "paradental cyst" is suggested as a second diagnosis. The final differential diagnosis between a small dentigerous or a paradental cyst and a pericoronal follicle depends on clinical and/or surgical findings, such as the presence of bone cavitation and cystic content.
\end{abstract}

UNITERMS: Tooth, unerupted; Dentigerous cyst.

\section{INTRODUCTION}

After the formation of enamel, the crown of the tooth is surrounded by the reduced enamel organ and by ectomesenchyma. These two structures form the pericoronal follicle, which can be the origin of several types of diseases during or after odontogenesis. Hamartomas and odontogenic cysts or tumors have been reported ${ }^{13,14,15,16,18,19,23 \text {, }}$ ${ }^{24,29,34}$. Abnormal pericoronal follicles have also been associated with some syndromes ${ }^{28}$.

The dentigerous cyst is a lesion frequently associated with unerupted teeth (UT). In the past, however, many cysts considered to be dentigerous turned out to be inflammatory paradental cysts ${ }^{1,5,31}$ or normal follicular variations erroneously diagnosed as cysts $^{9,10,13,19,24,30}$.

The pathologic processes associated with the pericoronal follicle can be early identified by radio- graphs that show an enlargement of the pericoronal space (PS). Exact measurements such as $2.0 \mathrm{~mm}, 2.5 \mathrm{~mm}$ and $5.0 \mathrm{~mm}$ in width have been used as radiographic parameters for the diagnosis of dentigerous cysts since $1961^{8,26,27,33}$.

In 1965 STANLEY et al. ${ }^{34,35}$ demonstrated that in UT the reduced enamel epithelium (REE) predominated in patients up to 22 years of age. The REE is then transformed into a stratified squamous epithelium (SSE) with the normal aging of the follicle. This information resulted in confusion and, sometimes, in the misdiagnosis of small dentigerous cysts $^{2,4,11,19,20,22,25,30}$. However, in 1987, radiographic and microscopic criteria were excluded from the diagnosis of small dentigerous cysts $^{10}$. It was stated that the diagnosis depended on clinical and/or surgical criteria such as the presence of bone cavitation and luminal cystic contents. Recent reports have supported this conclusion, em-

*Associate Professor, Department of Stomatology; **Pathologist, Lauro de Souza Lima Hospital of Dermatological Diseases; Retired Professor, Oral Pathology - School of Dentistry of Bauru, University of São Paulo, Brazil. 
DAMANTE, J. H.; FLEURY, R. N. A contribution to the diagnosis of the small dentigerous cyst or the paradental cyst. Pesqui Odontol

Bras, v. 15, n. 3, p. 238-246, jul./set. 2001.

phasizing the fact that the microscopic features of pericoronal follicles and dentigerous cysts are identical, with no possibility of differentiation ${ }^{9,13,18,19,24,30}$.

The purpose of the present study was to verify the relationship between the radiographically measured width of the PS and the microscopic features of the follicles of unerupted teeth (UT) and partially erupted teeth (PET) by investigating the role of inflammation and the relationship between this space and the type of epithelium. The study was carried out in order to contribute to the diagnosis of small pathological PS enlargements such as those that occur with small dentigerous cysts and paradental cysts.

\section{MATERIAL AND METHODS}

One hundred and thirty UT and 35 PET were radiographed and extracted. Teeth were considered partially erupted when any portion of the crown was clinically exposed in the mouth. The pericoronal follicles were submitted to microscopic evaluation. Most of the patients were in the second and third decades of life $(51.5 \%$ and $41.2 \%$, respectively). The teeth most frequently affected were lower third molars $(n=84)$ and upper third molars ( $\mathrm{n}=38)$, followed by canines $(\mathrm{n}=21)$, premolars $(\mathrm{n}=17)$ and eumorphic supernumerary teeth $(\mathrm{n}=5)$. The patients were randomly selected among those referred to the surgery clinic by dentists or by the departments of the School of Dentistry of Bauru.

The widest region of the PS was measured in periapical radiographs or in panoramic radio-

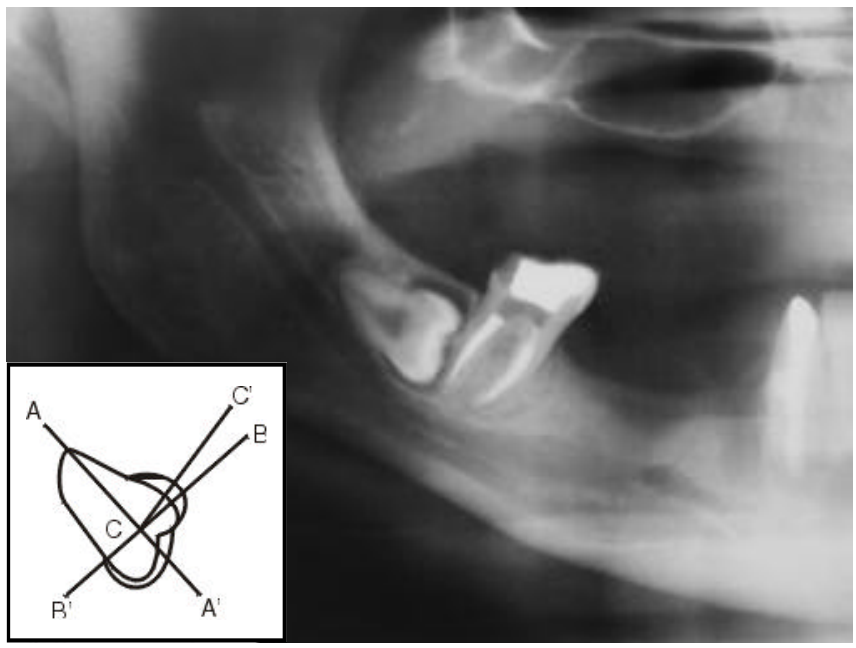

FIGURE 1 - Method utilized for measuring the pericoronal space. Width $=2 \mathrm{~mm}$. graphs. All panoramic radiographs were taken with the same X-ray machine (Ortopantomograph OP-3 - Palomex OY-Finland \& Siemens Corp-West Germany). The contours of the tooth and of the pericoronal space were traced on ultraphan paper. Two perpendicular lines (A-A' and B-B') were drawn on the image of the tooth, one passing through the long axis and the other, through the center of the crown (Figure 1). Starting from the intersection of the two lines, a ruler $\left(\mathrm{C}^{-} \mathrm{C}^{\prime}\right)$ was moved to the widest point of the PS, where the measurement was carried out with a caliper rule. The widest point was chosen because THOMA $^{36}$ has described a lateral form of dentigerous cyst. Image magnification in the panoramic radiographs was corrected using a reduction of $0.5 \mathrm{~mm}$, according to LARA ${ }^{22}$.

The teeth were carefully extracted by means of a routine technique and care was taken to preserve the follicle as much as possible. The surgeon was always looking for pericoronal bone cavitation and luminal cystic contents. In some cases, when the radiographic exam suggested the possibility of a cystic lesion, an aspiration biopsy was carried out before the surgery.

The follicles were macroscopically cut into semiserial sections, and 15 sections per specimen were stained with hematoxylin-eosin. The epithelium was identified as reduced enamel epithelium (REE) when the superficial cells were cylindrical (Figure 2) or cuboidal (Figure 3), resembling typical or reduced ameloblasts. When the superficial cells were flattened, the epithelium was identified as stratified squamous epithelium (SSE) (Figure 4) re-

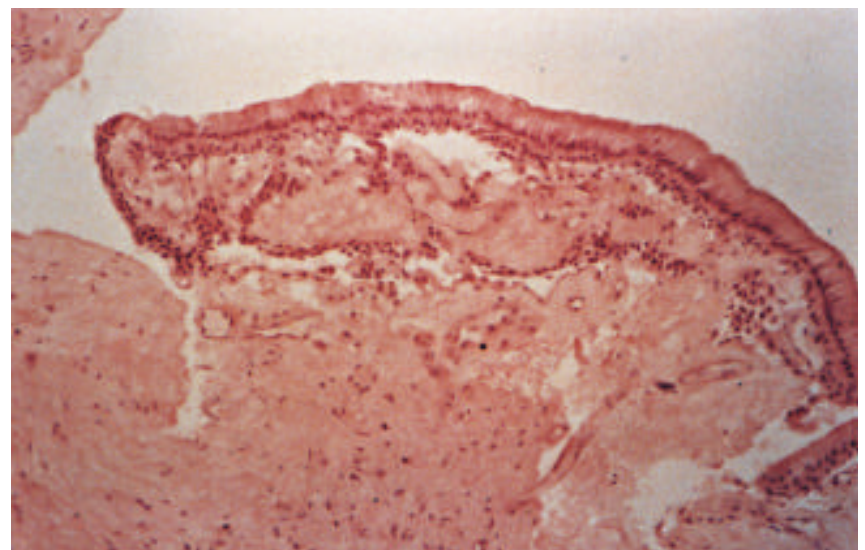

FIGURE 2 - Reduced enamel epithelium with high columnar superficial cells. Unerupted tooth. Pericoronal space of $1.3 \mathrm{~mm}$ (H.E., X 40). 
DAMANTE, J. H.; FLEURY, R. N. A contribution to the diagnosis of the small dentigerous cyst or the paradental cyst. Pesqui Odontol

Bras, v. 15, n. 3, p. 238-246, jul./set. 2001.

gardless of the number of layers or the organization of the basal layer. Hyperplasia was considered to be present when the number of layers exceeded twenty cell rows. The presence or absence of inflammation, classified as mild, moderate or intense, was evaluated on the ectomesenchymal wall (Figure 5).

In order to associate the different observed characteristics, the chi-square and Fisher tests were applied. Inflammation degrees were combined and considered as being present or absent. The width of the PS was divided into two groups (normal and enlarged). Enlargement was considered when the measured width was greater than $3 \mathrm{~mm}$.

\section{RESULTS}

The radiographic width of the PS of the speci-

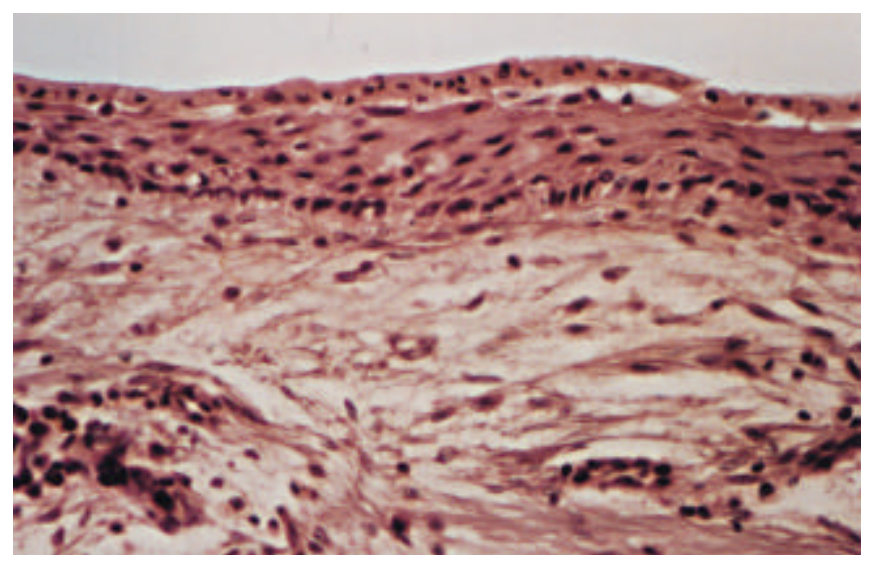

FIGURE 3 - Reduced enamel epithelium with cuboidal superficial cells and stratification of the underlying layers. Note the presence of a mild mononuclear infiltrate on the connective tissue wall. Unerupted tooth. Pericoronal space of 3.3. $\mathrm{mm}$ (H.E., X 160).

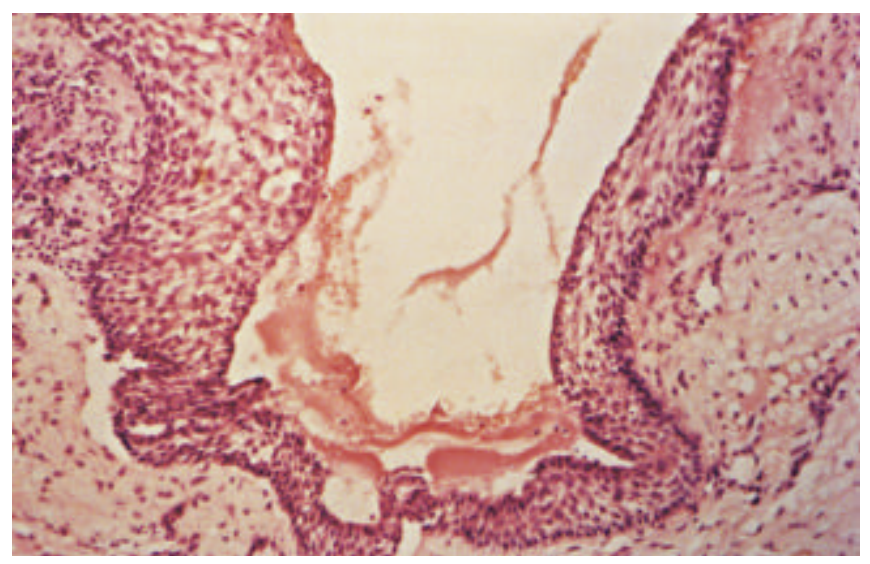

FIGURE 4 - Stratified squamous epithelium with intercellular edema. Partially erupted tooth (H.E., X 100). mens ranged from $0.1 \mathrm{~mm}$ to $5.6 \mathrm{~mm}$; it ranged from $1 \mathrm{~mm}$ to $3 \mathrm{~mm}$ in most cases $(86.6 \%)$ (Chart 1).

The REE was the most frequent type of epithelium in the follicles of UT (68.4\%) and inflammation was present in $36.1 \%$ of the cases. We also detected SSE in $20 \%$ of the cases, hyperplastic stratified squamous epithelium (HSSE) in 12.3\%, and the absence of epithelium (AE) in 13\% (Tables 1 and 2). In some follicles, two types of epithelium were present or there was transformation of REE into SSE (Figure 6). In the follicles of PET, the most frequent type of epithelium was the HSSE (68.5\%), and inflammation was present in $82.8 \%$ of cases. We also detected SSE in $17.1 \%$ of these follicles, $\mathrm{REE}$ in $5.7 \%$, and $\mathrm{AE}$ in $11.4 \%$ (Tables 3 and 4 ). The statistical analysis demonstrated no signifi-

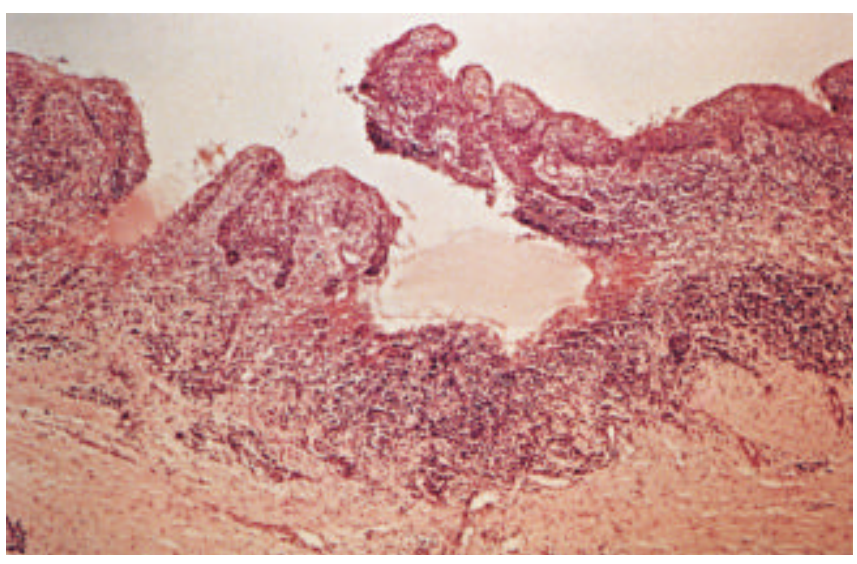

FIGURE 5 - Hyperplastic stratified squamous epithelium with numerous epithelial cristae. The connective tissue wall is intensely inflamed. Partially erupted tooth. Pericoronal space of $1.1 \mathrm{~mm}$ (H.E., X 40).

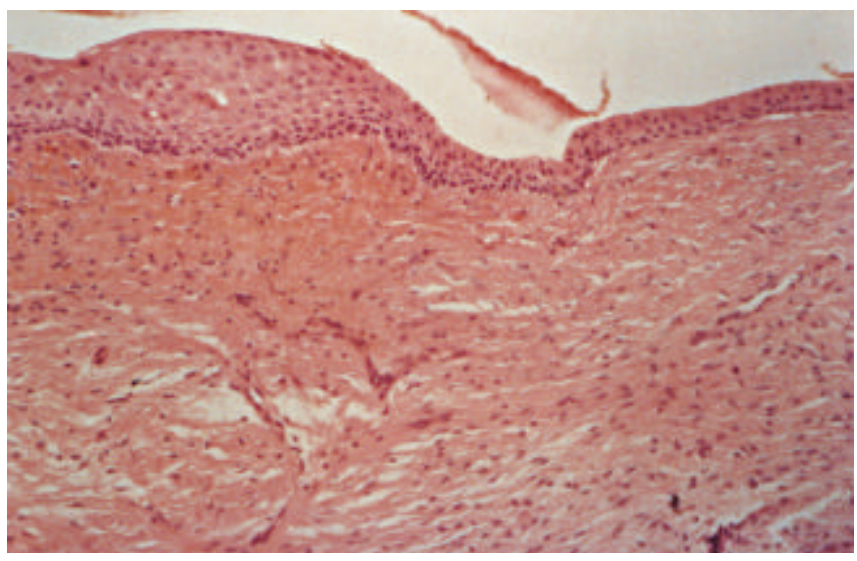

FIGURE 6 - Area of transition from the reduced enamel epithelium to the stratified squamous epithelium. Unerupted tooth. Pericoronal space of $2.8 \mathrm{~mm}$ (H.E., X 100). 
DAMANTE, J. H.; FLEURY, R. N. A contribution to the diagnosis of the small dentigerous cyst or the paradental cyst. Pesqui Odontol

Bras, v. 15, n. 3, p. 238-246, jul./set. 2001.

cant association between inflammation and width of the PS for both UT and PET ( $p>0.05)$. No significance was either observed between the type of epithelium and the width of the PS ( $p>0.05)$ except for the SEE in UT $(\mathrm{p}<0.05)$.

The main findings of this study are summarized below:

1. The radiographically measured pericoronal space (PS) width ranged from $1 \mathrm{~mm}$ to $3 \mathrm{~mm}$ in

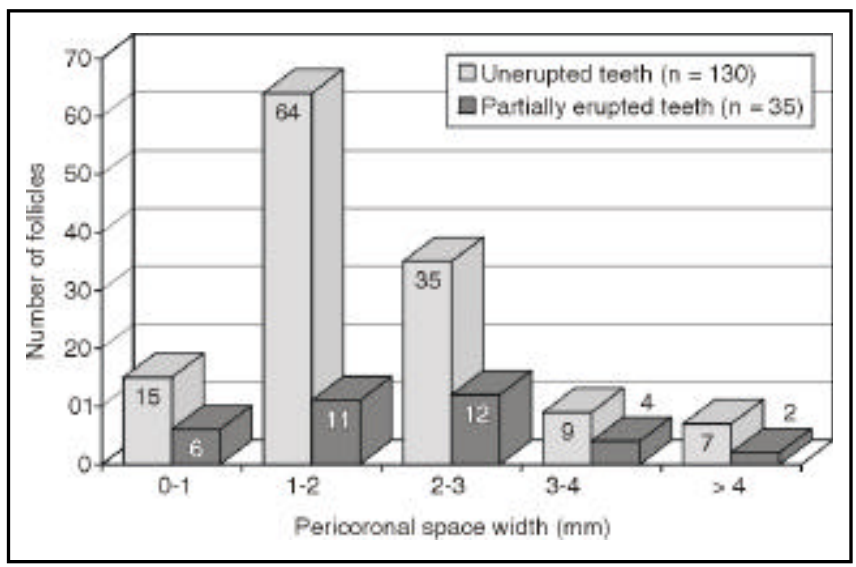

CHART 1 - Distribution of pericoronal follicles according to the width of the pericoronal space. most unerupted (UT) and partially erupted teeth (PET). These measurements correspond to normal follicles.

2. The pericoronal follicles of UT were most frequently lined by reduced enamel epithelium (REE). Those of PET were lined by hyperplastic stratified squamous epithelium (HSSE).

3. PS enlargements from $3.0 \mathrm{~mm}$ to $5.6 \mathrm{~mm}$ were frequently related to the presence of hyperplastic stratified squamous epithelium (HSSE) with different degrees of hyperplasia, and inflammation of connective tissue.

\section{DISCUSSION}

The relationship between pericoronal space, inflammation and lining epithelium

The distribution of the sample (Chart 1) shows that the majority of the PS widths ranged from $1 \mathrm{~mm}$ to $3 \mathrm{~mm}$. In our study, we defined as normal widths those smaller than $3 \mathrm{~mm}$. The definition was based on the distribution of our sample and on the consulted literature which describes normal parameters from $1.0 \mathrm{~mm}$ to $5.0 \mathrm{~mm}^{8,26,27,33}$.

Theoretically, inflammation should not be expected in follicles of UT but it was present in $36.1 \%$

TABLE 1 - Relationship between the epithelium of the pericoronal follicle and the pericoronal space enlargement in unerupted teeth.

\begin{tabular}{l|c|c|c|c|c|c}
\hline \multicolumn{1}{c|}{ Pericoronal space width (mm) } & $0-1$ & $1-2$ & $2-3$ & $3-4$ & $>4$ & Total \\
$\begin{array}{l}\text { Epithelium of the } \\
\text { pericoronal follicle* }\end{array}$ & $5(33.3 \%)$ & $48(75.0 \%)$ & $27(77.1 \%)$ & $7(77.7 \%)$ & $2(28.5 \%)$ & $89(68.4 \%)$ \\
\hline Reduced enamel epithelium & $4(26.6 \%)$ & $9(14.0 \%)$ & $8(22.8 \%)$ & $3(33.3 \%)$ & $4(57.1 \%)$ & $26(20.0 \%)$ \\
\hline Stratified squamous epithelium & $2(13.3 \%)$ & $11(17.1 \%)$ & $2(5.7 \%)$ & - & $2(28.5 \%)$ & $16(12.3 \%)$ \\
\hline Hyperplastic stratified squamous epithelium & $4(26.0 \%)$ & $9(14.0 \%)$ & $4(11.4 \%)$ & $1(11.1 \%)$ & - & $17(13.0 \%)$ \\
\hline Absent epithelium & 15 & 64 & 35 & 9 & 7 & 130 \\
\hline Total (n) &
\end{tabular}

*In some cases there was duplicity of epithelia. $\mathrm{n}$ - number of cases.

TABLE 2 - Relationship between inflammation of the pericoronal follicle and pericoronal space enlargement in unerupted teeth.

\begin{tabular}{l|c|c|c|c|c|c}
\hline \hline $\begin{array}{l}\text { Pericoronal space } \\
\text { width (mm) }\end{array}$ & $0-1$ & $1-2$ & $2-3$ & $3-4$ & $>4$ & Total \\
Inflammation & $6(40.0 \%)$ & $24(37.5 \%)$ & $9(25.7 \%)$ & $3(33.3 \%)$ & $5(71.4 \%)$ & $47(36.1 \%)$ \\
\hline Present & $9(60.0 \%)$ & $40(62.5 \%)$ & $26(74.3 \%)$ & $6(66.7 \%)$ & $2(28.6 \%)$ & $83(63.9 \%)$ \\
\hline Absent & 15 & 64 & 35 & 9 & 7 & 130 \\
\hline Total $(\mathrm{n})$ & \multicolumn{1}{|r|}{} \\
\hline \hline
\end{tabular}

$\mathrm{n}$ - number of cases. 
DAMANTE, J. H.; FLEURY, R. N. A contribution to the diagnosis of the small dentigerous cyst or the paradental cyst. Pesqui Odontol Bras, v. 15, n. 3, p. 238-246, jul./set. 2001.

of them (Table 2). That can be explained by two hypothesis: the first one is physiological. The erupting process occurs with an inflammation originating from the penetration of oral antigens into the wider intercellular spaces of the epithelial cells of the reduced enamel organ and oral epithelium. Many teeth could be erupting, although this process would not be completed. The second hypothesis is that many UT may communicate with the oral environment through a periodontal pocket of an adjacent tooth. We detected a few such cases using a periodontal probe, but these teeth were still classified as UT.

In PET, inflammation was present in $82.8 \%$ of the cases (Table 4). Some follicles may not have been totally removed during the surgery, which explains the presence of cases without inflammation. The surgical removal of follicles is never complete, especially in the areas attached to the oral mucosa. Unremoved parts continue to be attached to the surgical wounds.

By dividing the sample into teeth with normal and teeth with enlarged PS, we could calculate from Tables 2 and 4 that inflammation was present in $34 \%$ of the UT with normal PS and in $50 \%$ of the UT with enlarged PS. For PET, inflammation was present in $79 \%$ of the normal spaces and in $100 \%$ of the enlarged ones. Although there was no significant association between such parameters ( $p>0.05)$, the data suggest that the larger the PS, the greater the probability of existing inflammation, particularly for PET. That allows us to speculate that inflammation may be a determinant of the enlargement of the PS, despite the fact that inflammation was occasionally present in follicles whose PS varied from 0.1 to $5.6 \mathrm{~mm}$, in the general sample. Probably, the association is stronger for PET because tooth eruption generally occurs along with an inflammation process. This is supported by our findings in which only $20 \%$ of the normal PS had no inflammation and inflammation was present in $100 \%$ of the enlarged pericoronal spaces in PET. On the contrary, one could argue that inflammation is not causing enlargement of the PS because it was present in $79 \%$ of the PET with PS considered normal $(<3.0 \mathrm{~mm})$.

Although our data do not statistically support such association, we believe that inflammation is determinant in the widening of PS, mainly in PET, as it can be depicted from Tables 2 and 4 .

TABLE 3 - Relationship between the epithelium of the pericoronal follicle and the pericoronal space enlargement in partially erupted teeth.

\begin{tabular}{|c|c|c|c|c|c|c|}
\hline $\begin{array}{l}\text { Pericoronal space width }(\mathrm{mm}) \\
\begin{array}{l}\text { Epithelium of the } \\
\text { pericoronal follicle* }\end{array}\end{array}$ & $0-1$ & $1-2$ & $2-3$ & $3-4$ & $>4$ & Total \\
\hline Reduced enamel epithelium & $1(16.6 \%)$ & - & $1(8.3 \%)$ & - & - & $2(5.7 \%)$ \\
\hline Stratified squamous epithelium & $1(16.6 \%)$ & $3(27.2 \%)$ & $2(16.6 \%)$ & - & - & $6(17.1 \%)$ \\
\hline Hyperplastic stratified squamous epithelium & $4(66.6 \%)$ & $6(54.5 \%)$ & $8(66.6 \%)$ & $4(100 \%)$ & $2(100 \%)$ & $24(68.5 \%)$ \\
\hline Absent epithelium & - & $2(18.1 \%)$ & $2(16.6 \%)$ & - & - & $4(11.4 \%)$ \\
\hline Total (n) & 6 & 11 & 12 & 4 & 2 & 35 \\
\hline
\end{tabular}

*In some cases there was duplicity of epithelia. $\mathrm{n}$ - number of cases.

TABLE 4 - Relationship between inflammation of the pericoronal follicle and pericoronal space enlargement in partially erupted teeth.

\begin{tabular}{l|c|c|c|c|c|c}
\hline \hline $\begin{array}{r}\text { Pericoronal space } \\
\text { width (mm) }\end{array}$ & $0-1$ & $1-2$ & $2-3$ & $3-4$ & $>4$ & Total \\
Inflammation & $4(66.6 \%)$ & $8(72.7 \%)$ & $11(91.6 \%)$ & $4(100 \%)$ & $2(100 \%)$ & $29(82.8 \%)$ \\
\hline Present & $2(33.3 \%)$ & $3(27.3 \%)$ & $1(8.4 \%)$ & - & - & $6(17.2 \%)$ \\
\hline Absent & 6 & 11 & 12 & 4 & 2 & 35 \\
\hline Total $(\mathrm{n})$ &
\end{tabular}

$\mathrm{n}$ - number of cases. 
DAMANTE, J. H.; FLEURY, R. N. A contribution to the diagnosis of the small dentigerous cyst or the paradental cyst. Pesqui Odontol

Bras, v. 15, n. 3, p. 238-246, jul./set. 2001.

The relationship between the lining epithelium, inflammation and the PS width, was poor for UT (Tables 1 and 2), but was very clear for PET (Tables 3 and 4), where the REE almost disappeared, being substituted by HSSE. That suggests the existence of a relationship between inflammation, epithelial changes, particularly hyperplasia, and enlarged PS; however, the chi-square analysis was significant only for the presence of SSE and for PS enlargement in UT.

According to Table 1, it is also interesting to note that REE was present in the majority of the follicles $(68.4 \%)$ that were not in direct contact with the oral cavity. Epithelial lining was absent in $13 \%$ of the cases (Table 1), but when it was present, it was mostly discontinuous. That results from the ameloblastic adherence to the enamel cuticle, which detached from parts of the specimen during the surgical treatment. The absence of epithelium in the microscopic examination of the follicle has already been mentioned in the literature ${ }^{4,35}$ and it does not depend on the surgical care at the time of removal.

The presence of SSE in pericoronal follicles has already been mentioned by some authors ${ }^{2,4,6,35}$. According to ADELSPERGER et $a l^{2}$ and STANLEY et $a l^{35}$, SEE appears in follicles after the individual reaches 21 or 22 years of age, respectively. CONSOLARO $^{6}$ showed that there was, with aging, a tendency of transformation - REE into SEE but, any of the epithelia could be present in any age after normal eruption. We do know that this transformation normally occurs because, after amelogenesis, the ameloblasts turn from columnar into cuboidal cells and then become flattened (Figures 2, 3 and 6). The remaining layers are formed by the outer enamel organ epithelial cells and stratum intermedium.

We can not explain the significance of the association between SEE and PS enlargement in UT. We believe it was a casual find. We do not believe that the transformation of REE into SSE causes enlargement of the PS by itself. A recently published study showed squamous metaplasia of REE without changes in the $\mathrm{PS}^{2}$. We agree with those authors who described the SSE as a normal part of the follicle $e^{4,6,35}$. We follow the hypothesis that the relationship between inflammation, HSSE and PS enlargement represents a process that ends with the cystic transformation of the follicle. Some prospective studies have shown cystic transformation of the follicles ${ }^{16}$. However, the risk of this transformation remains unknown.

\section{The relationship between pericoronal space enlargement and the diagnosis of dentigerous cyst}

It is important to know the actual incidence of dentigerous cysts to recommend a prudent management therapy for UT. The lack of criteria for the diagnosis of small dentigerous cysts distorts the statistical values, increasing existing doubts. MOURSHED $^{26}$ found a $1.44 \%$ incidence of dentigerous cysts in a radiographic examination of unerupted teeth. KNIGHTS et $a l^{20}$, in a microscopic study, found dentigerous cysts in $44.70 \%$ of UT. On the other hand, KIM; ELLIS ${ }^{19}$ found that the most common histopathological mistake was to define pericoronal follicles as dentigerous cysts because of inadequate interpretation of the lining epithelium. EISENBERG ${ }^{11}$ emphasized the importance of interpreting the radiographic and clinical data when dealing with osseous pathology. Likewise, SCIUBBA ${ }^{30}$ criticized the results obtained by KNIGHTS et al. $^{20}$ because they were based only on microscopic studies. He pointed out the lack of criteria for decision when one depends on only one method of diagnosis. In a letter to the editor, KNIGHTS et $a l^{20}$ replied that they considered the transformation of the REE into SSE as pathological. That contradicts STANLEY; DIEHL ${ }^{34}$ for whom the metaplasia of the REE occurs with the aging process, followed by a decreasing incidence of cysts and tumors. In our opinion, and in spite of these conclusions, the literature continues to report misdiagnoses of dentigerous cyst ${ }^{17}$.

During the 70's and 80's, several researchers ${ }^{4,12,22,25}$ came to the conclusion that radiography alone was insufficient to diagnose small dentigerous cysts. Others failed to establish correct diagnoses when they chose the histopathological diagnosis based only on the lining epithelium. They assumed that the presence of the SSE was an indication of cyst. It is impossible to accept that the lining epithelium may characterize a dentigerous cyst for three main reasons. First, SSE was described in the pericoronal follicles in classical papers and was considered a normal variation of the aging process ${ }^{35}$. Second, the literature on dentigerous cysts has shown that this cyst has the same histological characteristics of follicles, thus preventing differentiation between 
DAMANTE, J. H.; FLEURY, R. N. A contribution to the diagnosis of the small dentigerous cyst or the paradental cyst. Pesqui Odontol

Bras, v. 15, n. 3, p. 238-246, jul./set. 2001.

the two entities ${ }^{9,10,13,30}$. Third, the very definition of cyst includes bone cavitation and luminal cystic contents $^{31}$. The histopathological diagnosis of a cyst may only be valid in conditions similar to those presented by AL-TALABANI; $\mathrm{SMITH}^{3}$, where all the cyst components were present. Our investigation showed us that pericoronal spaces up to 5.6-millimeter-wide presented neither bone cavitation nor luminal cystic contents and, therefore, they were not cysts. They were rather enlargements caused by a summation of factors such as inflammation and epithelial transformation as discussed above.

In 1995, DALEY; WYSOCKI ${ }^{9}$ proposed that the surgical criteria of bone cavitation and luminal cystic contents were the only trustworthy criteria to distinguish between dentigerous cyst and follicles with radiolucent areas larger than $4 \mathrm{~mm}$. This work ${ }^{9}$ reinforced the conclusions already mentioned in $1987^{10}$. According to SHEAR ${ }^{31}$, the definition of a cyst no longer includes the presence of a lining. Our data support the belief that clinical and/or surgical criteria are necessary to confirm a diagnosis of cyst in small PS enlargements.

According to EISENBERG ${ }^{11}$, the subject is of interest only for academic discussion since the surgical treatment is the same for follicles and small dentigerous cysts, despite the fact that some insurance carriers favor the diagnosis of dentigerous cyst for an arbitrary reimbursement. In a recent presentation about this theme ${ }^{32}$ we discussed this diagnosis with some scientists, who have also mentioned insurance problems. The economic factor is mentioned because there are countries where over $50 \%$ of the expense in oral and maxillofacial surgery occur as a result of the extraction of unerupted third molars.

\section{The relationship between pericoronal space enlargement and the diagnosis of paradental cyst}

The figures which express the incidence of dentigerous cysts have become inaccurate after CRAIG $^{7}$ (1976) first described the paradental cyst as a specific entity. Several cases of paradental cysts have been labeled as dentigerous. Additionally, a number of epidemiologic studies have also become inaccurate after the final separation of inflammatory cysts in the new WHO classification $^{21}$.
STANLEY et $a l^{35}$, mentioned some histological characteristics of radicular cysts in unerupted third molar follicles. They most certainly described paradental cysts. There was epithelial hyperplasia, intense inflammation, cholesterol crystals, macrophages and foreign body type giant cells. This picture has also been mentioned in AMÊNDOLA's work ${ }^{4}$. Both works have only shown a lack of clinical and surgical criteria to describe small inflammatory cysts.

Based on these reports from the literature, we have divided our sample into UT and PET, and most of the teeth were third molars, the main site of occurrence of paradental cysts ${ }^{1,5,31}$.

None of the cases we have studied have fulfilled the diagnostic criteria of paradental or dentigerous cysts, despite a pericoronal radiolucency of up to $5.6 \mathrm{~mm}$. There are consistent radiographic features of a paradental cyst that should be recognized: the cyst is small, located on the distobuccal aspect of the tooth ${ }^{1}$ and its image is often covered by the radiopacity of the crown. Sometimes, the surgeon can only discover the cavity and its contents when he elevates the flap. The dissection of the cyst is easier than that of a follicle because the walls are thicker. Pericoronal infiltration of anesthetic should be avoided because the solution may press the follicle leading to the misdiagnosis of a paradental cyst. We therefore suggest the following protocol for the final diagnosis of PS enlargements: in most cases of UT or PET, the radiologist should choose inflammation as the primary diagnosis and dentigerous or paradental cyst as a second diagnosis. The clinician and/or surgeon should observe the presence or absence of bone cavitation and its luminal cystic contents which will differentiate the pericoronal follicle from the dentigerous cyst or the paradental cyst. The material must be thoroughly examined microscopically. The pathologist, when interpreting clinical, surgical and radiographic data, will confirm or refute the diagnosis. Only the pathologist will be able to rule out the existence of keratocysts, hamartoplasias, incipient ameloblastomas or other lesions associated with pericoronal follicles.

\section{CONCLUSIONS}

1. Inflammation seems to be associated with PS 
DAMANTE, J. H.; FLEURY, R. N. A contribution to the diagnosis of the small dentigerous cyst or the paradental cyst. Pesqui Odontol Bras, v. 15, n. 3, p. 238-246, jul./set. 2001.

enlargement in PET and possibly in UT but, the data were not statistically significant.

2. In most of the routine cases of PS enlargement, the first radiographic diagnosis should be "inflammation of the follicle". The hypothesis of "dentigerous cyst" or "paradental cyst" is suggested as a second diagnosis.

3. The final differential diagnosis between small dentigerous cyst or paradental cyst and perico- ronal follicle depends on clinical and/or surgical findings, such as the presence of bone cavitation and cystic content.

\section{ACKNOWLEDGMENTS}

The authors thank Dr. José Roberto Pereira Lauris, Dr. Eliete Neves da Silva, Dr. Ricardo Marins de Carvalho and Dr. Carla Andreotti Damante for their help.

DAMANTE, J. H.; FLEURY, R. N. Contribuição para o diagnóstico do pequeno cisto dentígero ou do cisto paradentário. Pesqui Odontol Bras, v. 15, n. 3, p. 238-246, jul./set. 2001.

Foi propósito deste estudo verificar a relação entre a largura do espaço pericoronário (EP) medida radiograficamente e os aspectos microscópicos do folículo. O objetivo foi contribuir com o diagnóstico de pequenos cistos dentígeros e cistos paradentários. Cento e trinta dentes não-irrompidos (DNI) e trinta e cinco dentes parcialmente irrompidos (DPI) foram radiografados e extraídos. O estudo radiográfico consistiu na medição da largura do EP seguida pelo exame microscópico do folículo. A largura do EP variou de 0,1 a 5,6 mm. O revestimento mais freqüentemente observado em DNI foi o epitélio reduzido do esmalte $(\mathrm{ERE}=68,4 \%)$. Em DPI foi o epitélio pavimentoso estratificado hiperplásico $(\mathrm{EPEH}=68,5 \%)$. Inflamação estava presente em 36,1\% dos DNI e 82,8\% dos DPI. Houve uma associação estatisticamente significante entre a presença de epitélio pavimentoso estratificado (EPE) com o alargamento do espaço pericoronário em DNI $(\mathrm{p}<0,05)$. Houve uma tendência da inflamação estar associada com o alargamento do EP em DPI. Em espaços pericoronários menores que $5,6 \mathrm{~mm}$ não foram detectados cavidade óssea e conteúdo cístico cirurgicamente. Na maioria dos casos clínicos de rotina com alargamento do EP, sugerimos que o primeiro diagnóstico radiográfico deva ser "folículo inflamado". "Cisto dentígero" ou "cisto paradentário" deve ser sugerido como segundo diagnóstico. O diagnóstico diferencial final entre um pequeno cisto dentígero ou cisto paradentário e um folículo pericoronário dependerá de achados clínicos e/ou cirúrgicos de cavidade e conteúdo.

UNITERMOS: Dente não-erupcionado; Cisto dentígero.

\section{BIBLIOGRAPHIC REFERENCES}

1. ACKERMANN, G.; COHEN, M. A.; ALTINI, M. The paradental cyst: a clinicopathologic study of 50 cases. Oral Surg Oral Med Oral Pathol, v. 64, p. 308-312, 1987.

2. ADELSPERGER, J. et al. Early soft tissue pathosis associated with impacted third molars without pericoronal radiolucency. Oral Surg, v. 89, n. 4, p. 402-406, Apr. 2000.

3. AL-TALABANI, N. G.; SMITH, C. J. Experimental dentigerous aspects and enamel hipoplasia, their possible significance in explaining the pathogenesis of human dentigerous cysts. J Oral Pathol, v. 9, p. 82-91, 1980.

4. AMÊNDOLA, C. H. P. Estudo radiográfico e histopatológico do espaço e membranas pericoronárias de terceiros molares inferiores não-irrompidos. Bauru, 1983. Tese - Faculdade de Odontologia de Bauru, Universidade de São Paulo.

5. BOHAY, R. N.; WEINBERG, S.; THORNER, P. S. The paradental cyst of the mandibular permanent first molar: report of a bilateral case. ASDC J Dent Child, v. 59, p. 361-365, 1992.

6. CONSOLARO, A. Caracterização microscópica de folículos pericoronários de dentes não-irrompidos e parcialmente irrompidos - sua relação com a idade.
Bauru, 1987. Tese - Faculdade de Odontologia de Bauru, Universidade de São Paulo.

7. CRAIG, G. T. The paradental cyst: a specific inflammatory odontogenic cyst. Br Dent J, v. 141, p. 9-14, 1976.

8. DACHI, S. F.; HOWELL, F. V. A survey of 3.874 routine full-mouth radiographs. II: a study of impacted teeth. Oral Surg, v. 14, p. 1165-1169, 1961.

9. DALEY, T. D.; WYSOCKI, G. P. The small dentigerous cyst: a diagnostic dilemma. Oral Surg Oral Med Oral Pathol Oral Radiol Endod, v. 79, p. 77-81, 1995.

10. DAMANTE, J. H. Estudo dos foliculos pericoronários de dentes não-irrompidos e parcialmente irrompidos. Inter-relação clínica, radiográfica e microscópica. Bauru, 1987. Tese (Livre-Docência) - Faculdade de Odontologia de Bauru, Universidade de São Paulo.

11. EISENBERG, E. Discussion. Dental follicular tissue: misinterpretation as odontogenic tumors. J Oral Maxillofac Surg, v. 51, p. 767-768, 1993.

12. FIGUEIREDO, S. V. Importância do exame radiográfico no diagnóstico diferencial entre saco folicular e cisto dentigero (estudo realizado através da medida do espaço pericoronal em radiografias e comparação histológica). Belo Horizonte, 1970. Tese - Faculdade de Odontologia de Belo Horizonte, Universidade Federal de Minas Gerais. 
DAMANTE, J. H.; FLEURY, R. N. A contribution to the diagnosis of the small dentigerous cyst or the paradental cyst. Pesqui Odontol

Bras, v. 15, n. 3, p. 238-246, jul./set. 2001.

13. FUKUTA, Y.; TOTSUKA, M.; TAKEDA, Y.; YAMAMOTO, H. Pathological study of the hyperplastic dental follicle. $\mathbf{J}$ Nihon Univ Sch Dent, v. 33, p. 166-173, 1991.

14. GARDNER, D. G. The central odontogenic fibroma: an attempt at clarification. Oral Surg, v. 50, p. 425-432, 1980 .

15. GARDNER, D. G.; RADDEN, B. Multiple calcifying hyperplastic dental follicles. Oral Surg Oral Med Oral Pathol Oral Radiol Endod, v. 79, p. 603-606, 1995.

16. GIROD, S. C.; GERLACH, K. L.; KRUEGER, G. Cysts associated with long-standing impacted third molars. Int $\mathbf{J}$ Oral Maxillofac Surg, v. 22, p. 110-112, 1993.

17. GLOSSER, J. W.; CAMPBELL, J. H. Pathologic change in soft tissues associated with radiographically "normal" third molar impactions. Br J Oral Maxillofac Surg, v. 37, p. 259-260, 1999.

18. HIRSHBERG, A.; BUCHNER, A.; DAYAN, D. The central odontogenic fibroma and the hyperplastic dental follicle: study with Picrosirius red and polarizing microscopy. $\mathbf{J}$ Oral Pathol Med, v. 25, p. 125-127, 1996.

19. KIM, J.; ELLIS, G. L. Dental follicular tissue: misinterpretation as odontogenic tumors. J Oral Maxillofac Surg, v. 51, p. 762-768, 1993.

20. KNIGHTS, E. M.; BROKAW, W. C.; KESSLER, H. P. The incidence of dentigerous cysts associated with a random sampling of unerupted third molars. Gen Dent, v. 39, p. 96-98, 1991.

21. KRAMER, I. R. H.; PINDBORG, J. J.; SHEAR, M. The WHO histological typing of odontogenic tumours. Cancer, v. 70, p. 2988-2994, 1992.

22. LARA, H. R. O. Contribuição ao estudo da correlação entre a imagem radiográfica e o aspecto histológico dos sacos pericoronários normais e dos cistos dentígeros. Porto Alegre, 1982. Tese - Faculdade de Odontologia de Porto Alegre, Universidade Católica do Rio Grande do Sul.

23. LEIDER, A. S.; EVERSOLE, L. R.; BARKIN, M. E. Cystic ameloblastoma: a clinicopathologic analysis. Oral Surg Oral Med Oral Pathol, v. 60, p. 624-630, 1985.

24. LUKINMAA, P. L.; HIETANEN, J.; ANTTINEN, J. et al. Contiguous enlarged dental follicles with histologic features resembling the WHO type of odontogenic fibroma. Oral Surg Oral Med Oral Pathol, v. 70, p. 313-317, 1990.

25. MOREIRA DÍAZ, E.; RUIZ, M. D. V.; ALONSO, L. R. R. Estudio de la correlación entre la imagem radiográfica y el aspecto hístico del saco pericoronário de los terceros molares retenidos. Rev Cubana Estomat, v. 14, p. 137-144, 1977.

26. MOURSHED, F. A. Roentgenographic study of dentigerous cysts. I: incidence in a population sample. Oral Surg, v. 18, p. 47-53, 1964.

27. MOURSHED, F. A. Roentgenographic study of dentigerous cysts. II: role of roentgenograms in detecting dentigerous cyst in the early stages. Oral Surg, v. 18, p. 54-61, 1964.

28. ROBERTS, M. W.; BLAKEY, G. H.; JACOWAY, J. R. et al. Enlarged dental follicles, a follicular cyst, and enamel hypoplasia in a patient with Lowe syndrome. Oral Surg Oral Med Oral Pathol, v. 77, p. 264-265, 1994.

29. SANDLER, H. J.; NERSASIAN, R. R.; CATALDO, E. et al. Multiple dental follicles with odontogenic fibroma-like changes (WHO type). Oral Surg Oral Med Oral Pathol, v. 66, p. 78-84, 1988.

30. SCIUBBA, J. J. Evaluating dentigerous cysts. Gen Dent, v. 39, p. 313-315, 1991. Letter.

31. SHEAR, M. Cysts of the oral regions. 3. ed. Oxford : Wright PSG, 1992.

32. SILVA, E. N.; FLEURY, R. N.; CHINELLATO, L. E. M. et al. Relation between the width of the pericoronary space and some microscopic aspects of the follicle. J Dent Res, v. 76, p. 854. 1997. (Special Issue)

33. STANLEY, H. R.; ALATTAR, M.; COLLET, W. K. et al. Pathological sequel of "neglected" impacted third molars. J Oral Pathol, v. 17, p. 113-117, 1988.

34. STANLEY, H. R.; DIEHL, D. L. Ameloblastoma potential of follicular cysts. Oral Surg, v. 20, p. 269-278, 1965.

35. STANLEY, H. R.; KROGH, H.; PANNKUK, E. Age changes in the epitelial components of follicles (dental sacs) associated with impacted third molars. Oral Surg, v. 19, p. 128-139, 1965.

36. THOMA, K. H. The circunferencial dentigerous cyst. Oral Surg, v. 18, p. 368-371, 1964.
Recebido para publicação em 02/08/00

Enviado para reformulação em 20/02/01

Aceito para publicação em 08/06/01 